University of Nebraska - Lincoln

DigitalCommons@University of Nebraska - Lincoln

USDA National Wildlife Research Center - Staff Publications
U.S. Department of Agriculture: Animal and Plant Health Inspection Service

\title{
$9-2011$
}

\section{Physical and behavioural abilities of commensal rodents related to the design of selective rodenticide bait stations}

\author{
William C. Pitt \\ National Wildlife Research Center, will.pitt@aphis.usda.gov \\ Robert T. Sugihara \\ USDA/Wildlife Services, National Wildlife Research Center \\ Laura C. Driscoll \\ USDA/APHIS/WS National Wildlife Research Center \\ Daniel S. Vice \\ Animal and Plant Health Inspection Service
}

Follow this and additional works at: https://digitalcommons.unl.edu/icwdm_usdanwrc

Pitt, William C.; Sugihara, Robert T.; Driscoll, Laura C.; and Vice, Daniel S., "Physical and behavioural abilities of commensal rodents related to the design of selective rodenticide bait stations" (2011). USDA National Wildlife Research Center - Staff Publications. 1341.

https://digitalcommons.unl.edu/icwdm_usdanwrc/1341

This Article is brought to you for free and open access by the U.S. Department of Agriculture: Animal and Plant Health Inspection Service at DigitalCommons@University of Nebraska - Lincoln. It has been accepted for inclusion in USDA National Wildlife Research Center - Staff Publications by an authorized administrator of DigitalCommons@University of Nebraska - Lincoln. 


\title{
Physical and behavioural abilities of commensal rodents related to the design of selective rodenticide bait stations
}

\author{
William C. Pitt ${ }^{a *}$, Robert T. Sugihara ${ }^{a}$, Laura C. Driscoll ${ }^{a}$ and Daniel S. Vice ${ }^{b}$ \\ "U.S. Department of Agriculture, Animal and Plant Health Inspection Service, Wildlife Services, National Wildlife Research Center, \\ Hawait Field Station, PO Box 10880, Hilo 96721, Hawaii; "U.S. Department of Agriculture, Animal and Plant Health Inspection \\ Service, Wildlife Services, 233 Pangelinan Way, Barrigada, Guam 96913
}

(Received 5 November 2010; final version received 7 February 20II)

\begin{abstract}
Design of selective bait stations to deliver rodenticide bait is often proposed for management of non-target animal access. but much of the information on the behavioural and physical capabilities of rodents relative to station access has not been readily available or is based on unpublished, informal observations or anecdotes repeated for many years. We studied the climbing and jumping abilities of Polynesian Rats (Rattus exulans), Norway Rats ( $R$. norvegicus), Roof Rats (R. rattus), and House Mice (Mus musculus), focused on applications for eradication of these invasive rodents from island ecosystems in the Pacific where a variety of important non-target animals occur. The maximum jumping heights achieved by the three rat species was $40 \mathrm{~cm}$; House Mice jumped a maximum of $25 \mathrm{~cm}$. The minimum diameter holes through which these species could pass were $40 \mathrm{~mm}$ (Norway Rats), $35 \mathrm{~mm}$ (Roof Rats), $30 \mathrm{~mm}$ (Polynesian Rats), and $13 \mathrm{~mm}$ (House Mice). Our findings establish threshold differences for these species for transiting access openings or jumping to platforms to obtain food. In areas where endangered birds or other animals occur, such information could be used in designing selective stations so as to prevent unnecessary poisoning.
\end{abstract}

Keywords: bait station; rodenticide; rodent behaviour; rodent control; rodent eradication

\section{Introduction}

Application of rodenticide bait is a common method for controlling rodents in and around structures and agricultural areas and for eradicating introduced rodents from island ecosystems (Taylor et al. 2000; Veitch and Clout 2002; Rao 2003; Vantassel et al. 2006). Many materials and commercial formulations are approved by various regulatory authorities worldwide; generally these are cereal-based and are readily accepted by a variety of animals, vertebrate and invertebrate. Use of rodent feeding stations, or bait delivery stations, has been the technique of choice for many rodent control applications, where their use is required by law or regulation, or where there is a serious concern regarding non-target bait 'take' by other wild animals or pets (Howard 1987; Jacobs 1990; Taylor et al. 2000; Nelson et al. 2002). Such stations also have application in the monitoring of rodent presence or activity (Howard et al. 1979; Phillips et al. 2007). Although standard bait stations could be optimised for selective use by rats and mice, the entry opening and design of many custom-constructed or commercially available bait stations may also permit access by opportunistic feeders including other rodent species, birds, reptiles, amphibians, terrestrial crabs, and other small non-target animals. Such designs sometimes result in toxic bait exposure to rare or protected species, nuisance bait removal reducing control programme efficiency, or compromised monitoring efforts. Many operators have made creative modifications (for example, station design, reduced entry openings, or above-ground placement) to exclude bait 'take' by these non-target species. However, either: (1) the effect of these modifications on target rodent access is typically not evaluated and only the reduced access to non-target animals is considered; or (2) stations are designed based on presumptions about rodent behaviour, then tried and modified. Many of these efforts proceed under operational conditions with the results unevaluated and never published. Recent exceptions are Erickson et al. (1990), Whisson (1999), and Phillips et al. (2007). Nonetheless, it may be easier and more practical to manipulate station type rather than bait type to resolve the problem of non-target species' exposure to rodenticides.

Commercial rat bait stations typically have openings of 52--58 mm (Howard 1987; Monro and Dennis 1990; Vantassel et al, 2006). A common practice to restrict non-target entry, particularly birds, is to secure a stout wire or nail vertically across the bait station opening, reducing the entry size by half. Such modifications may also selectively exclude some species

*Corresponding author. Email: will.pitt(a aphis.usda.gov 
of target rodents or larger sized cohorts of a target species. Elevating bait stations above-ground out of reach of ground dwelling or foraging non-target animals, such as birds, reptiles, and land crabs, may also potentially reduce use by some rodent species that normally forage on or near the ground or have limited climbing or jumping ability.

Most rodent eradication, control, or monitoring programmes are poorly documented; unsuccessful projects are more likely to have minimal or obscure, unpublished documentation. Successful rat eradication projects using bait stations have been reported on Buck Island (Witmer 1998; Witmer et al. 2007) and from preliminary work on Rose Atoll, where bait stations positioned above-ground to exclude land crabs and other ground-foraging animals (Ohashi and Oldenburg 1992).

Bait removal from bait stations by hermit crabs and coconut crabs has been widely recognized as a problem in rodent eradication projects (Wegman 2008) and was a major problem in an operation to eradicate rats from Palmyra Atoll in which two of us were involved. Bait station modifications including capping one end of the tube, anchoring it to the ground, or raising it onto a platform did not eliminate bait 'take' by crabs. Such crabs were a preferred food item for the bristle-thighed curlew (Numenius tahitiensis), a bird species of conservation concern on the atoll. Use of an alternative above-ground bait station provided some degree of exclusion of crabs, however, the rat eradication effort was ultimately declared unsuccessful. It is uncertain, but possible, that bait station modifications to exclude non-target land crabs in such situation also reduced use by rodents. Future eradication attempts on Pacific islands may benefit from the development and use of bait stations that provide complete exclusion of land crabs, as well as accessibility to all rodent target species.

The physical abilities of the common invasive rodent species have rarely been studied and reports of original work are generally difficult to find and obtain. Much of the information available regarding the climbing or jumping ability of rodents or their abilities to pass through holes or restricted openings is based on unpublished, informal observations or on old anecdotes that have been repeated for many years, often losing the original sources and any qualifying observations (Williams 1948; Brown 1960; Brooks 1962; Mallis 1964). Such observations have typically been associated with attempts at rodent exclusion and shipboard rodent control. Thus, hole sizes are typically expressed as the maximum size (less than $6 \mathrm{~mm}$ for mice and less than $13 \mathrm{~mm}$ for rats) that prevent all individuals from entering (Marsh 1994; Timm 1994a, 1994b). The jumping ability of rodents has typically been described as the maximum height attained by a single individual, probably with hazing, or has been based on the performance of trained laboratory animals (Hansgen 1972; Davis 1979). The House Mouse (Mus musculus) has been documented jumping higher than $24 \mathrm{~cm}$, Rattus norvegicus jumping higher than $77 \mathrm{~cm}$, and R. rattus jumping higher than $150 \mathrm{~cm}$. in height (Meehan 1984), but these observations are of little use in determining how high bait stations can be placed or how small of a hole will allow access by all individuals of a particular species.

Boulenger (1919) experimentally determined rats' abilities related to digging around barriers and entering openings in traps. Denney (1937) and Johnson (1946) used experimental approaches to evaluate rat guards for ships to determine effective means of preventing rats from climbing or jumping around such devices. Spurr et al. $(2006,2007)$ evaluated several commercial bait stations to determine preferences by $R$. norvegicus and $R$. rattus. Buckle and Prescott (2011) found substantial reductions in food consumption by $R$. norvegicus from tamper-resistant bait stations compared with open food trays. Kaukeinen (1988) and Morris and Kaukeinen (1988) addressed the further need to also consider neophobia (a behaviour prominent among rats) (Shorten 1954; Barnett 2009), or individual exploratory behaviour in evaluating commercial bait stations for rats and mice, while West et al. (1975) examined how bait station design and use could reduce competition among rodents to achieve the more sustained feeding periods necessary for anticoagulant rodenticides to be consumed in sufficient amounts.

We examined physical and behavioural capabilities of rodents related to their abilities to access feeding stations with the intent of providing a technical basis for design or modification of selective bait stations used in rodent management. Ideally, effective bait stations should allow free access by all individuals of a target species while excluding all non-target animals. We studied Polynesian Rats ( $R$. exulans), Norway Rats ( $R$. norvegicus), Roof Rats ( $R$. rattus), and House Mouse and were particularly focused on applications for eradication of these species from island ecosystems in the Pacific where a variety of important non-target animals are of immediate concern. For these four species, we examined access behaviour related to two design characteristics: entry opening and height above ground.

\section{Materials and methods}

Wild rodents were live-trapped around Hilo, Hawaii and transported to our laboratory for testing. They were first quarantined and acclimated to the laboratory environment in individual cages. During and following this acclimation period, they were provided with a maintenance diet of laboratory rodent chow (5001 Rodent Diet, PM Nutrition International, Brentwood, MO, USA) and water supplied ad libitum.

Two types of device were used in these tests. A polyvinyl chloride (PVC) pipe device was used to assess 
the appropriate size of entry holes for each species. An elevated platform was used to determine the height to which animals of each species could jump to gain access to food. Animals of varying size classes (sub adults and adults) of each species were arbitrarily selected from the laboratory pool for testing. In each test, the maintenance diet was removed, the test device was provisioned with fresh coconut chunks (a very aromatic and attractive alternative food for rodents), and the animal was either provided a test device in its home cage (Series I) or moved to the test chamber (Series II). To both standardise exposure periods and remove potential learned biases to the test devices or to the food material, new animals were used for each trial. The number of each species used in the tests depended on the results of field collections, our goal being a minimum of 12 animals for each test.

\subsection{Test Series I: entry opening}

We determined the minimum hole size that all individuals of a particular species may pass via by enticing rodents to enter various sized circular holes in PVC pipe. For rats, each pipe section $(15 \mathrm{~cm} \times 17.8$ $\mathrm{cm}$, diameter $\times$ length) had an entry hole drilled on one side and was placed upright in an individual animal's holding cage $(24.1 \mathrm{~cm} \times 48.3 \mathrm{~cm} \times 17.8$ $\mathrm{cm})$, so that the top and bottom of the pipe were wedged against the ceiling and floor of the cage; the only access to the coconut chunks placed inside the pipe was through the entry hole. The entry holes were positioned $2 \mathrm{~cm}$ above floor level for all rat species. For mice, a pipe section $(4 \mathrm{~cm} \times 12.7 \mathrm{~cm}$, diameter $\times$ length) was capped on the ends with the entry hole drilled on one side and was placed horizontal in the cage. The entry holes were positioned less than $1 \mathrm{~cm}$ above floor level for all mice. An animal that did not enter the test pipe in the first $24 \mathrm{~h}$ in Series 1 tests was then placed inside the pipe device (with the coconut chunks placed outside) for an additional $24 \mathrm{~h}$ to assure that it was unable to navigate its way through the hole. We cvaluated entry holes diameters ranging from 20 to $58 \mathrm{~mm}$ at $5-\mathrm{mm}$ intervals for rats, and 11 and $13 \mathrm{~mm}$ for mice. In addition, we examined whether rats could pass through a $58-\mathrm{mm}$ hole divided by a 9-gauge (3 mm) wire.

\subsection{Test Series II: placement height}

For this test series, individual rats were moved to a $1.5 \times 1.5 \times 1.4-\mathrm{m}$ stainless steel enclosure, with their normal food and water supplied ad libitum. A small inverted plastic box $(15 \times 25 \times 15 \mathrm{~cm}$, with entry opening) was placed at one corner of this enclosure to provide a refuge site. An attractive food (coconut chunks) was placed on an easily accessible $15 \times 15-\mathrm{cm}$ wooden platform apparatus centred in the enclosure. An infra-red camera was used to record rodent activity. In this setting, we tested rodents' ability to gain access to food on the platform when it was successively elevated, so that access was possible only by the animal jumping vertically onto the platform. After an animal's acclimation to feeding from the platform, a test series was initiated, raising the platform incrementally to 15 , $20,25,30,35,40 \mathrm{~cm}$ (Mus musculus) or $20,30,40,50$ (Rattus sp.), increasing the height after each successful feeding attempt. Video tapes were reviewed during each trial, and animals that failed to jump high enough to gives access to the platform were considered unsuccessful. Animals that did not jump to the platform at its lowest height were tested a second time over an additional $24 \mathrm{~h}$ with only the food on the platform available.

\section{Results}

The results of the two test series (maximum vertical jumping height, Table 1) and (minimum hole size accessed, Table 2) were generally consistent with the limited literature reports, although the information was not available for all species and, as we found in review, much of it was anecdotal. Relative to the sizes of the four species, there were some differences that suggest selective bait delivery might be possible by altering feeding station design. The same testing approach could be used with non-target species, including native rodents, crabs, lizards, tortoises, and other animals that may interfere with rodent control operations.

\subsection{Feeding platform height}

The maximum jumping heights achieved by all individual animals tested are reported in Table 1 .

Table 1. Species, number, weight, and maximum height that all individuals tested of each species jumped vertically to access food on a suspended platform.

\begin{tabular}{lcccc}
\hline & & \multicolumn{2}{c}{ Weight } & Maximum jumping height achieved \\
\cline { 3 - 4 } Species & $N$ & Mean $\pm \mathrm{SE}(\mathrm{g})$ & Range $(\mathrm{g})$ & $\begin{array}{c}\text { by all individuals (cm) } \\
\text { Rattus rattus }\end{array}$ \\
Rattus norvegicus & 20 & $126.0 \pm 5.0$ & $87.6-172.5$ & 40 \\
Rattus exulans & 14 & $162.2 \pm 14.3$ & $71.1-258.6$ & 40 \\
Mus musculus & 18 & $64.3 \pm 2.9$ & $46.6-86.0$ & 40 \\
\hline
\end{tabular}


Table 2. Species, number, weight, and minimum diameter of holes that all individuals of each species could pass to reach food.

\begin{tabular}{|c|c|c|c|c|}
\hline \multirow[b]{2}{*}{ Species } & \multirow[b]{2}{*}{$N$} & \multicolumn{2}{|c|}{ Weight } & \multirow{2}{*}{$\begin{array}{l}\text { Minimum diameterof hole passed } \\
\text { by all individuals }(\mathrm{mm})\end{array}$} \\
\hline & & Mean $\pm \mathrm{SE}(\mathrm{g})$ & Range (g) & \\
\hline Ratlus rathus & 16 & $124.6 \pm 5.8$ & $85.0-161.6$ & 35 \\
\hline Rathus norvegicus & 12 & $180.8 \pm 12.4$ & $112.1-258.1$ & 40 \\
\hline Ratnes exulans & 41 & $62.0 \pm 2.2$ & $21.2-87.0$ & 30 \\
\hline Mus musculus & 23 & $10.7 \pm 0.4$ & $6.2 \cdots 15.2$ & 13 \\
\hline
\end{tabular}

Twenty Roof Rats ranging in weight from 87.6 to 172.5 $\mathrm{g}($ mean $\pm \mathrm{SE}=126.0 \pm 5.0 \mathrm{~g}$ ) all jumped to a $40-\mathrm{cm}$ platform to feed. Fourteen Norway Rats (71.1-258.6 g, $162.2 \pm 14.3 \mathrm{~g})$ and 18 Polynesian Rats $(46.6-86.0 \mathrm{~g}$, $64.3 \pm 2.9 \mathrm{~g})$ also fed from the $40-\mathrm{cm}$ high platforms. Forly-two House Mice $(9.0-16.7 \mathrm{~g}, 11.9 \pm 0.3 \mathrm{~g})$ were all able to jump to a $25-\mathrm{cm}$ high feeding platform.

\subsection{Opening size for accessing food}

The minimum diameters of feeding station openings that all individuals tested could pass to obtain food are shown in Table 2. Sixteen Roof Rats ranging in weight from 85.0 to $161.6 \mathrm{~g}$ (mean $\pm \mathrm{SE}=124.6 \pm 5.8 \mathrm{~g}$ ) all gained access to food by passing a $35-\mathrm{mm}$ diameter hole. Twelve Norway Rats (112.1-258.1 g, $180.8 \pm 12.4 \mathrm{~g}$ ) could pass through a $40-\mathrm{mm}$ hole. Forty-one Polynesian Rats $(21.2-87.0 \mathrm{~g}, 62.0 \pm 2.2 \mathrm{~g})$ passed through $30-\mathrm{mm}$ holes. The 23 House Mice tested $(6.2-15.2 \mathrm{~g}, 10.7 \pm 0.4 \mathrm{~g})$ were all able to gain access to food by passing through $13-\mathrm{mm}$ holes. All of the rats tested, including the large Norway Rats, passed through the standard commercial bait station $58-\mathrm{mm}$ entry holes divided by wire; however, we expected that the results for rodents attempting to cnter irregular openings in structures would be highly variable compared with the circular holes used for bait stations.

\section{Discussion}

Our findings establish the general threshold differences in transiting access openings or jumping to platforms to obtain food for the four species of rodents that are commonly found as invasive predators on islands in the Pacific. Since use of rodenticide bait stations will be the preferred method for rodent control or eradication on many of the small islands where they have become a problem, the information we have gathered will assist managers in avoiding impacts on non-target animals. In areas where endangered birds or invertebrates occupy the same habitats as invasive rodents, such information, used for designing selective bait stations, could reduce non-target species exposure to rodenticides. Likewise, the problem of invertebrate interference with rodenticide bait may be resolved by selective bait station design.
Our preliminary work has addressed the physical abilities of rodents. Additional work may be required for actual rodent control operations using this information to overcome the problems of non-target rodenticide exposure. In this regard, based on previous failures of expensive, complex rodent eradication efforts, it is critically important that conservation managers recognise the problems of non-target effects and interference during the early planning phase of such operations and conduct the necessary testing or obtain the additional information needed for effective rodenticide bait delivery.

We also believe that the information obtained in this study and the test protocols used will be of future value in rodent control activities involving these species where non-target access or interference with stations by pets, poultry, or livestock may be anticipated. In addition, these findings will be of use on situations involving the need for protected trap placement or long-term rodent population monitoring or reinvasion indicator devices (such as chew block) at monitoring stations.

An alternative interpretation of our results, with respect to either rats entering or exiting holes or jumping onto feeding platforms, would be that animals were attempting escape and accidently ended in a situation where food was available. We did not observe behaviour that would indicate such generalised escape attempts and our limited observations suggested that rodents fed on the elevated platforms rather than removing the coconut bits. Our experience here and in previous works has been that introduction of wild rodents into new cages, provided they are handled gently and not disturbed, results in an initial burst of exploratory behaviour of varying length, followed by acclimation to the new environment. The odour of the coconut bait undoubtedly was very strong and probably directional in the test cage, providing animals a means of orientation to the food source. Barnett (2009) discussed this phenomenon at some length, since his classic studies involved introduction of rats into small cages; he generally discounted 'escape' as a motivating factor for caged rats.

\section{Acknowledgements}

This research was funded by the National Wildlife Research Center, USDA/APHIS/Wildlife Services as Protocol QA 
1264. Institutional Animal Care and Use Committee approval was received March 25, 2005. We thank Gary W Witmer for assistance with protocol development, Rogelio $\mathrm{E}$ Doratt for assistance with data analysis, and Michael W. Fall for assistance with report preparation and for helpful discussion of rat behaviour. Comments by Peter Dunlevy and an anonymous reviewer helped us improve the manuscript.

\section{References}

Barnett SA. 2009. The ral: A study in behaviour. Piscataway (NJ): Aldine Transaction Publishers, Rutgers University.

Boulenger EG. 1919. Report on methods of rat destruction. Proc Zool Soc Lond. 1919:227-244.

Brooks JE. 1973. A review of commensal rodents and their control. Crit Rev Environ Control. 3(4):405-453.

Brown RZ. 1960. Biological factors in domestic rodent control. U.S. Department of Health, Education, and Welfare, Communicable Disease Center, Atlanta.

Buckle AP, Prescott CV. 2011. Effects of tamper-resistant bait boxes on bait uptake by Norway rats (Rattus norregicus Berk.). Int J Pest Manage. 57(1):77-83.

Davis RA. 1979. Unusual behaviour by Rattus norvegicus. I Zool Lond. 188:298.

Denney OE. 1937. Some experiments with rats and rat guards. Public Health Rep. 52(23):723-726. 8 plates

Erickson WA. Marsh RE, Halvorson WL. 1990. A roof rat bait station that excludes deer mice. Wild Soc Bull. 18:319-325.

Hansgen KH. 1972. Distances jumped by Norway rats during competition. Calif Vector Views. 19:67.

Howard WE. 1987. Rodent-free using permanent bait stations. In: Richards CGJ, Ku TY, editors. Control of mammal pests. New York (NY): Taylor and Francis. p. 147-154.

Howard WE. Park JS, Cho WS, Kim SI. 1979. A safe and inexpensive way of making South Korean villages rodentfree. In: Beck JR, editor. Vertebrate pest control and management materials. Philadelphia (PA): American Society for Testing and Materials. p. 50-57.

Jacobs W. 1990. Required use of protective bait stations in the U.S. Proc Vertebr Pest Conf. 14:36-42.

Johnson MS. 1946. Notes on preventing rats from boarding ships. In: Natl Res Counc Abstr Bull, Insect Control Comm. Washington (DC). p. 174.

Kaukeinen DE. 1988. Evaluation of rodent bait station use under controlled conditions. In: Shumake SA, Bullard $\mathrm{RW}$, editors. Vertebrate pest control and management materials. Philadelphia (PA): American Society for Testing and Materials. p. 103114

Mallis A. 1964. Handbook of pest control, 4th ed. New York (NY): McNair-Dorland.

Marsh RE. 1994. Roof rats. In: Hygstrom SE, Timm RM, Larson GE, editors. Prevention and control of wildlife damage. Washington (DC): Univ Nebraska Coop Ext, U.S. Department of Agriculture, and Great Plains Agricultural Council. p. B125-B132.

Meehan AP. 1984. Rats and mice, their biology and control East Grinstead (UK): Rentokil Ltd.

Monro R, Dennis R. 1990. Tamper-resistant bait stations for rats an investigation into various designs. Pest Manag. 9:14 18 .

Morris KD, Kaukeinen DE. 1988. Comparative evaluation of tamper-proof mouse bait stations. Proc Vertebr Pest Conf. 13:101-106

Nelson JT. Woodworth BL, Fancy SG, Lindsey GD, Tweed EJ. 2002. Effectiveness of rodent control and monitoring techniques for a montane rain forest. Wild! Soc Bull 30:82-92.
Ohashi TJ, Oldenburg JG. 1992. Endangered species in the Pacific Islands: The role of animal damage control. Proc Vertebr Pest Conf. 15:32-35.

Phillips RB, Harris DB, Snell HL. 2007. Bait stations for detection and control of alien rats in Galapagos. J Wildl Manag. 71:2736-2742.

Rao AMKM. 2003. Rodent problems in India and strategies for their management. In: Singleton GR, Hinds LA. Krebs CJ, Spratt DM, editors. Rats, mice and people: Rodent biology and management. Canberra (Australia): Australian Centre for International Agricultural Research. p. 203-212.

Shorten M. 1954. Reaction of the brown rat towards changes in its environment. In: Chitty D, Southern HN, editors. Control of rats and mice. Vol. 2, Ch. 5. Oxford: Clarendon Press. p. 307-334

Spurr EB, Morriss GA, Turner J, O'Connor CE, Fisher P. 2007. Bait station preferences of ship rats. Dept Conservation, Wellington. (www.doc.govt.nz/upload/documents/ science-and-technical/DRDS271.pdf; accessed April 13, 2010).

Spurr EB, O'Connor CE, Morriss GA, Turner J. 2006. Bait station preferences of Norway rats. Dept Conservation. Wellington. (www.doc.govt.nz/upload/documents/scienceand-technical/drds255.pdf; accessed $A$ pril 13, 2010).

Taylor RH, Kaiser GW, Drever MC. 2000. Eradication of Norway rats for recovery of seabird habitat on Langara Island. Columbia. Restor Ecol. 8:151-160.

Timm RM. 1994a. House mice. In: Hygstrom SE. Timm RM, Larson GE, editors. Prevention and control of wildlife damage. Washington (DC): Univ Nebraska Coop Ext, U.S. Department of Agriculture, and Great Plains Agricultural Council. p. B31-B46.

Timm RM. 1994b. Norway rats. In: Hygstrom SE, Timm RM, Larson GE, editors. Prevention and control of wildlife damage. Washington (DC): Univ Nebraska Coop Ext, U.S. Department of Agriculture, and Great Plains Agricultural Council. p. B105-B120.

Vantassel S, Hyngstrom S, Ferraro D. 2006. Bait stations for controlling rats and mice. NebGuide G1646. Lincoln (NE, USA): Ext Inst of Agric Nat Resour, Univ Nebraska.

Veitch CR, Clout MN. editor. 2002. Turning the tide: The eradication of invasive species. IUCN SSC Invasive Species Specialist Group, Gland and Cambridge.

Wegman A. 2008. Land crab interference with eradication projects: Phrase I - compendium of available information. New Zealand: Pacific Invasives Initiative, Univ Auckland. (http://www.issgorg/cii/Electronic\%20references/pii/land_ crab_interference_with_rodent_erdication_projectspdf; accessed January $5 \overline{2} 011$ )

West RR, Fall MW, Libay JL. 1975. Reducing interactions among rats to improve bait acceptance. Philippine Agric. 59:31-36.

Whisson DA. 1999. A modified bait station for California ground squirrel control in endangered kangaroo rat habitat. Wildl Soc Bull. 27:172 177

Williams CL. 1948. The ship rat. Pest Control Sanit. 3:8-13.

Witmer G.. 1998. Rat management for endangered species protection in the U.S. Virgin Islands. Proc Vertebr Pest Conf. 18:281-286.

Witmer GW. Boyd F, Hillis-Starr Z. 2007. The successful eradication of introduced roof rats (Rattus rattus) from Buck Island using diphacinone, followed by an irruption of house mice (Mus musculus). Wildl Res. 34:108-115. 